Revista Brasileira de Farmacognosia Brazilian Journal of Pharmacognosy 21(3): 532-536, May./Jun. 2011

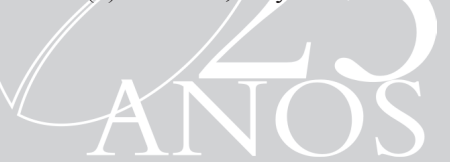

Article

Received 3 Dec 2009

Accepted 30 Aug 2010

Available online 17 Jun 2011

Keywords:

challenge test

preservative system

Schinus terebinthifolius

ISSN 0102-695X

doi: 10.1590/S0102-695X2011005000102

\section{Evaluation of a preservative system in a gel containing hydroalcoholic extract of Schinus terebinthifolius}

\author{
Túlio Flávio A. L. Moura, ${ }^{*}$, Fernanda N. Raffin, ${ }^{1}$ Ana Lourdes \\ R. Santos ${ }^{2}$
}

\author{
${ }^{1}$ Departamento de Farmácia da Universidade Federal do Rio Grande do \\ Norte, Brazil, \\ ${ }^{2}$ Programa de Pós-graduação em Ciências Farmacêuticas da Universidade \\ Federal do Rio Grande do Norte, Brazil.
}

\begin{abstract}
Currently, microbial contamination is one of the major problems faced by the phytomedicine industry with respect to the quality of the raw materials. The objective of this study was to evaluate the effectiveness of a preservative system in a formulation with hydrogel containing hydroalcoholic extract of Schinus terebinthifolius Raddi, Anacardiaceae ("aroeira" or "Brazilian Peppertree"), through the challenge test. The extracts were prepared by maceration at a ratio of 1:10 plant/solvent in $40 \%$ alcohol. Gel samples were artificially contaminated with separate inocula of Aspergillus niger, Candida albicans, Escherichia coli, Staphylococcus aureus and Pseudomonas aeruginosa and the number of viable microorganisms determined in triplicate by the "pour plate" method for counting colonies at 0, 24 and 48h, 7, 14, 21 and 28 days. The addition of the preservatives (methyl and propylparaben) in the "aroeira" gel proved to be effective against the studied species when the samples were evaluated using the challenge test. According to the criterion A of the European Pharmacopoeia, it was verified that the hydrogel product showed good conservation in a 28 days period.
\end{abstract}

\section{Introduction}

The species Schinus terebinthifolius Raddi, Anacardiaceae, is popularly known as "aroeira" or "Brazilian Peppertree". It is a plant frequently used in the treatment of skin and mucous membrane injuries and ulcers and in respiratory, digestive and genitourinary systems infections (Bacchi, 1986).

The bark of Schinus terebinthifolius is rich in tannins (Matos, 1994) which are related to various biological activities attributed to the "aroeira": antiinflammatory, antibacterial, antifungal, anticarcinogenic and antimutagenic (Simões et al., 1999). The tannins and polyphenols, present in large amounts in this plant, are considered as chemical markers in the quality control of this species (Ministério da Saúde, 1994).

Leal et al. (1996) studied the antimicrobial activity of gelled forms of Schinus terebinthifolius used for vaginal treatments, showing their efficacy against $S$. aureus. Subsequent studies have confirmed this activity against Staphylococcus aureus, Pseudomonas aeruginosa, Escherichia coli, Candida albicans and Aspergilus niger in different gels (Amorim \& Santos,
2003 Melo Jr. et al., 2003; Arias et al., 2004).

Studies of Amorim \& Santos, (2003) showed that the gel with $S$. terebinthifolius can be used for the treatment of bacterial vaginosis in non-pregnant women, showing an $84 \%$ cure rate. However, the presence of alkyl phenols in preparations based on "aroeira" materials can cause allergic reactions in the skin and mucous membranes, therefore the use of these products requires caution (Lorenzi \& Matos, 2008).

Due to the evidences of efficacy against the viability of a variety of microorganisms, a hydrogel containing hydroalcoholic extract of $S$. terebinthifolius bark was prepared for topical use. Considering the antimicrobial activity reported for this plant species, a preservative action from this extract, when incorporated to a gel, could be equally expected, as it has been reported for other species (Nostro, 2002; Manou, 1998).

However, there may be problems in the preservation of the product due to high water content present in the preparation. In addition, the contamination from the raw materials and the product handling steps can elevate the microbial load; however, these factors 
can be minimized by using a suitable preservative system. The parabens are among the substances commonly used as preservatives. The inhibitory concentrations of propylparaben and methylparaben for P. aeruginosa ATCC 9027 and S. aureus ATCC 6538 ranges around 4000 and $2000 \mu \mathrm{g} / \mathrm{mL}$ respectively (Handbook of excipients, 1994).

Thus, the goal of this work was to evaluate through the challenge test, the efficacy of a preservative system consisting of methyl and propyl parabens in a hydrogel containing hydroalcoholic extract of $S$. terebinthifolius.

\section{Materials and Methods}

\section{Hydrogel}

The material object of this study consisted of a formulation of hydrogel containing hydroalcoholic extract of Schinus terebinthifolius Raddi, Anacardiaceae, as presented in Table 1. The G1 formulation did not contain the preservative system, while the G2 formulation contained the parabens. The G3 and G4 formulations did not contain the plant extract, but had the preservative system added to the first one and not to the last.

Table 1. Gel formula containing the Schinus terebinthifolius Raddi, Anacardiaceae extract.

\begin{tabular}{lc}
\hline Plurigel $^{\circledR}$ & $2 \%$ \\
Propilene glycol & $5 \%$ \\
Propylparabenen & $0,6 \%$ \\
Methylparaben & $0,3 \%$ \\
Hydroalcoholic extract of S. terebinthifolius & $16 \%$ \\
Purified water by Reverse Osmosis & q.s.f. $100 \mathrm{~mL}$ \\
\hline Adjusted pH to 6.0 with $5 \% \mathrm{NaOH}$ solution &
\end{tabular}

The Plurige ${ }^{\circledR}$, an acrylate derived polymer, was provided by the Galena, the propylene glycol by Donghwa Surveyors \& Adjusters Corporation and the methyl and propyl paraben preservatives were obtained from Ueno Fine Chemicals Industry Ltd.

The hydroalcoholic extract of Schinus terebinthifolius was obtained from bark previously dried in a circulating air oven (Fabbe), at $45^{\circ} \mathrm{C}$ for five days and grinded in a hard tool steel blades mill (Marconi, model MA 048) through maceration in 40\% alcohol in a ratio of $1: 10(\mathrm{w} / \mathrm{v})$, plant:solvent for five days resulting in a concentration of $7 \%$ total tannins and $8.53 \%$ total polyphenols, from which values were determined by the spectrophotometer method validated by Vasconcelos (Vasconcelos, 2003).

\section{Culture media}

The culture media used (Himedia) were prepared from the dehydrated complex mixture and sterilized according to the manufacturer's instructions. Soyabean casein agar was used for the bacteria inoculation and Sabouraud-dextrose agar for the fungi inoculation.

\section{Diluent}

Monobasic potassium phosphate buffer at $\mathrm{pH}$ 7.2 with $1 \%$ of polysorbate 80 was used to neutralize the action of the parabens. This solution was sterilized through autoclaving at $121^{\circ} \mathrm{C}$ for $15 \mathrm{~min}$.

\section{Microorganisms}

The microorganisms used to assess the antimicrobial efficacy of the preservative system were: Staphylococcus aureus ATCC 6538, Pseudomonas aeruginosa ICQS 00230, Escherichia coli ATCC 8793, Candida albicans ICQS and Aspergillus niger ICQS 40036 and were all kindly provided by the Instituto Oswaldo Cruz-RJ. Inoculum for the bacteria and yeast were obtained from strains of 24 to $48 \mathrm{~h}$ subcultures, incubated at a temperature of $35^{\circ} \mathrm{C}$. The inoculum for the filamentous fungus was obtained from the strain of a 7 to 14 days subculture at room temperature.

\section{Preparation and standardization of the microorganisms' suspensions}

The bacteria were cultivated in soyabean casein slant agar at $30-35^{\circ} \mathrm{C}$ for $24 \mathrm{~h}$ and the fungi in Sabourauddextrose agar at $20-25^{\circ} \mathrm{C}$ for $48 \mathrm{~h}$ for the yeast and seven days for the mold. The cell mass was collected in $9 \mathrm{~mL}$ of sterile saline solution and the resulting suspension submitted to viable cell counts $(\mathrm{CFU} / \mathrm{mL})$ by the pour plate method stab culture seeding method (United States Pharmacopoeia, 2006).

The standardized microorganism suspensions were transferred to Petri dishes $(1 \mathrm{~mL})$ along with the same volume of the 1:10 dilution of "aroeira" gel samples and placebo with and without preservative in phosphate buffer containing the neutralizer. The aliquots were homogenized with 15-20 mL of culture media and cooled down at 45 ${ }^{\circ} \mathrm{C}$ afterwards. The assays for the bacteria and fungi were incubated at $35^{\circ} \mathrm{C}$ for $48 \mathrm{~h}$, and at $25^{\circ} \mathrm{C}$ for five days respectively. The controls for testing if polysorbate 80 , used as a neutralizer of the preservatives, did not interfere in the inhibitory effect of the test article were set in parallel. (United States Pharmacopoeia, 2006).

\section{Challenge test}

Gel samples containing extract of $S$. terebinthifolius without preservatives $(\mathrm{G} 1)$ and with the 
mixture of parabens (G2), plus placebo, i.e. gel without the extract but with the preservatives (G3) and placebo without preservatives (G4) were submitted to the challenge test.

Batches of $50 \mathrm{~g}$ of each sample, packed in sterile polyethylene tubes, were inoculated separately with the microorganisms. The volume of the inoculum was differentiated in order to provide a final suspension concentration in the product of $10^{6} \mathrm{CFU} / \mathrm{g}$.

All tubes were homogenized manually for 1 min immediately after the inoculation and the obtained suspension was submitted to serial dilution and plated for viability count $(\mathrm{CFU} / \mathrm{g})$ using the pour plate method. The determination of the number of viable microorganisms was made immediately after the inoculation and after 24 and $48 \mathrm{~h}, 7,14,21$ and 28 incubation days (European Pharmacopoeia, 2002).

\section{Results and Discussion}

The assays to prove the inactivation of the preservative systems demonstrated the efficacy of the neutralizing agents, since there was no inhibition of microbial growth in any of the groups tested.

Table 2 presents the counts for viable microorganisms during the challenge test, and the logarithms are shown in Figures 1 to 3.

The antimicrobial effectiveness in each sample was evaluated by the criterion A of interpretation of the European Pharmacopoeia (2002), which advocates a reduction of two logarithmic cycles in two days, three logarithmic cycles in seven days, no changes in fourteen days and remaining without changes until the $28^{\text {th }}$ testing day for bacteria. As for the fungi this same Pharmacopoeia reports a decrease of two logarithmic cycles in fourteen days and no increase in 28 days.

According to this criterion, it can be concluded that the preservative system used in this study shows satisfactory efficacy towards the tested microorganisms. When considering the product in study, the "aroeira" gel added with preservative (G2), the analysis of the results for the bacteria showed a reduction of two logarithmic cycles in $48 \mathrm{~h}$ and remaining unchanged until the $28^{\text {th }}$ testing day. A reduction of three logarithmic cycles in fourteen days was observed for the fungus and of five logarithmic cycles for the yeast, with the outcomes remaining unchanged for both until the $28^{\text {th }}$ testing day (Figure 1).

On the other hand, the evaluation of the placebo containing the preservative system (G3), showed a reduction of two logarithmic cycles for A. niger in $48 \mathrm{~h}$ and no increase up to the 28th day, however there was no reduction for $C$. albicans in this same period and the reduction for the yeasts occurred only in seven days. As for the bacteria, this hydrogel based product proved to be well conserved, since there was no evidence of bacterial growth throughout the test period (Figure 2). The fact that

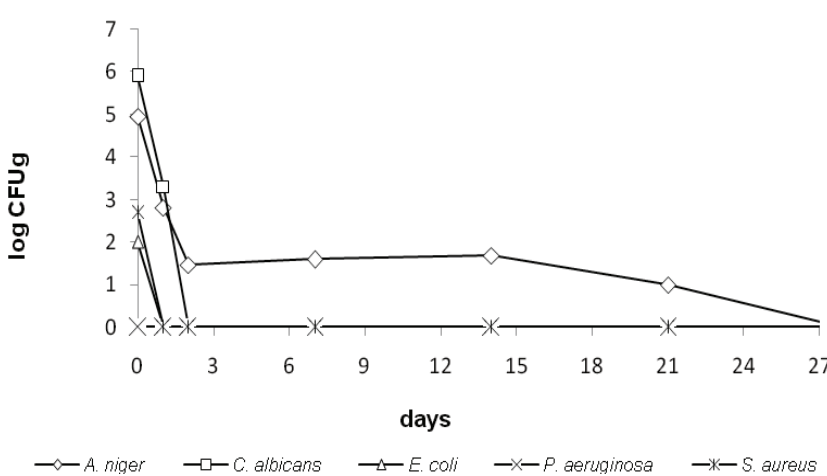

Figure 1. Deadly curve profile $\log \mathrm{CFU} / \mathrm{g} x$ day for the aroeira gel with preservation system (formulation G2).

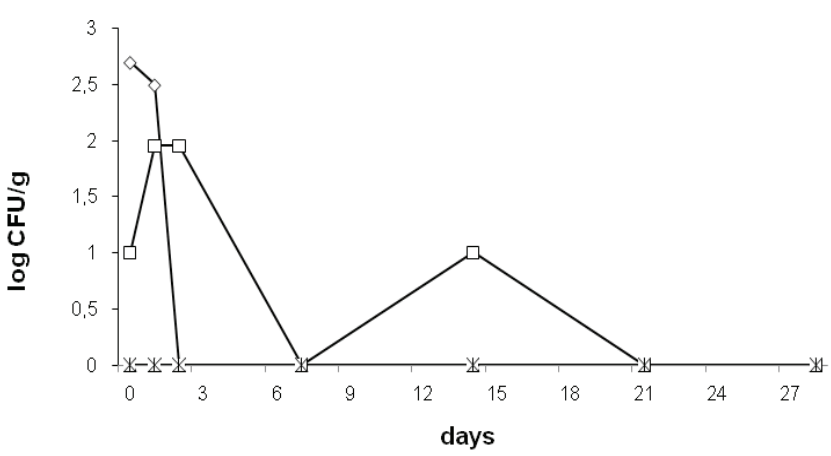

$\sim$ A. niger $\rightarrow$ C. albicans $\rightarrow$ E.coli $\rightarrow$ P. aeruginosa $\rightarrow$ *- S. aureus

Figure 2. Deadly curve profile $\log \mathrm{CFU} / \mathrm{g} x$ day for the placebo with preservation system (formulation G3).

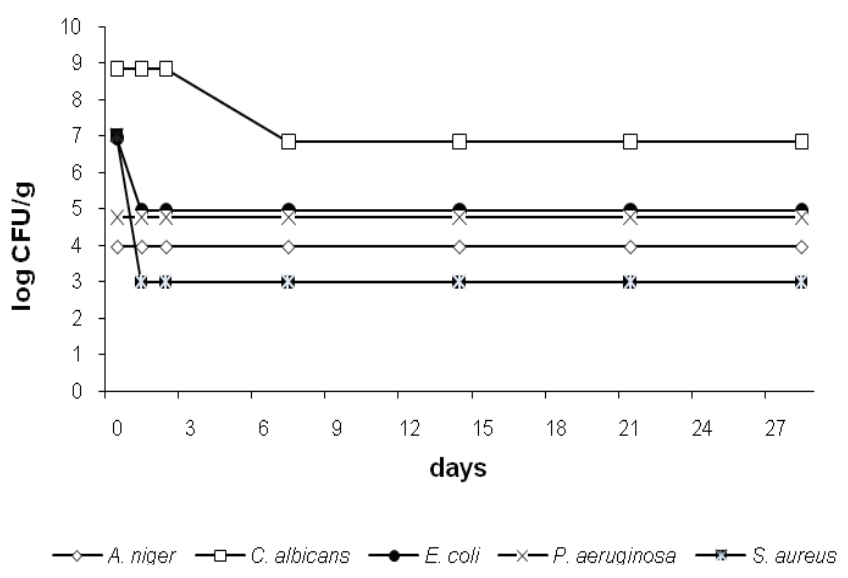

Figure 3. Deadly curve profile $\log \mathrm{CFU} / \mathrm{g} x$ day for the aroeira gel without preservation system (formulation G1).

the product based on the "aroeira" extract containing the preservatives presented good conservation towards $C$. albicans, and that the same result with the placebo was not observed, suggests that synergism might have occurred between the extract compounds and the preservatives. Synergic actions from phenolic compounds present in the lichen Heteroderma leucomela (L.) Poelt displaying 
Table 2. Number of viable (CFU/g) of P. aeruginosa, E. coli, S. aureus, C. albicans and A. niger in the effictiveness of preservatives test.

\begin{tabular}{|c|c|c|c|c|c|c|c|c|c|}
\hline \multirow[b]{2}{*}{ Gel } & \multirow[b]{2}{*}{ Microorganisms } & \multirow[b]{2}{*}{ Inoculum } & \multicolumn{7}{|c|}{ Time } \\
\hline & & & $0 \mathrm{~h}$ & $24 \mathrm{~h}$ & $48 \mathrm{~h}$ & 7 days & 14 days & 21 days & 28 days \\
\hline \multirow[t]{5}{*}{ G1 } & A. niger & $9.1 \times 10^{4}$ & $9 \times 10^{3}$ & $9 \times 10^{3}$ & $9 \times 10^{3}$ & $9 \times 10^{3}$ & $9 \times 10^{3}$ & $9 \times 10^{3}$ & $9 \times 10^{3}$ \\
\hline & C. albicans & $7.2 \times 10^{9}$ & $7 \times 10^{8}$ & $7 \times 10^{8}$ & $7 \times 10^{8}$ & $7 \times 10^{6}$ & $7 \times 10^{6}$ & $7 \times 10^{6}$ & $7 \times 10^{6}$ \\
\hline & E. coli & $9 \times 10^{7}$ & $9 \times 10^{6}$ & $9 \times 10^{4}$ & $9 \times 10^{4}$ & $9 \times 10^{4}$ & $9 \times 10^{4}$ & $9 \times 10^{4}$ & $9 \times 10^{4}$ \\
\hline & P. aeruginosa & $6 \times 10^{9}$ & $6 \times 10^{4}$ & $6 \times 10^{4}$ & $6 \times 10^{4}$ & $6 \times 10^{4}$ & $6 \times 10^{4}$ & $6 \times 10^{4}$ & $6 \times 10^{4}$ \\
\hline & S. aureus & $1.6 \times 10^{10}$ & $1 \times 10^{7}$ & $1 \times 10^{3}$ & $1 \times 10^{3}$ & $1 \times 10^{3}$ & $1 \times 10^{3}$ & $1 \times 10^{3}$ & $1 \times 10^{3}$ \\
\hline \multirow[t]{5}{*}{ G2 } & A. niger & $9.1 \times 10^{4}$ & $9 \times 10^{4}$ & $6,5 \times 10^{2}$ & $3 \times 10^{1}$ & $4 \times 10^{1}$ & $5 \times 10^{1}$ & $1 \times 10^{1}$ & $<10$ \\
\hline & C. albicans & $7.2 \times 10^{9}$ & $8 \times 10^{5}$ & $2 \times 10^{3}$ & $<10$ & $<10$ & $<10$ & $<10$ & $<10$ \\
\hline & E. coli & $9 \times 10^{7}$ & $1 \times 10^{2}$ & $<10$ & $<10$ & $<10$ & $<10$ & $<10$ & $<10$ \\
\hline & P. aeruginosa & $6 \times 10^{9}$ & $<10$ & $<10$ & $<10$ & $<10$ & $<10$ & $<10$ & $<10$ \\
\hline & S. aureus & $1.6 \times 10^{10}$ & $5 \times 10^{2}$ & $<10$ & $<10$ & $<10$ & $<10$ & $<10$ & $<10$ \\
\hline \multirow[t]{5}{*}{ G3 } & A. niger & $9 \times 10^{4}$ & $5 \times 10^{2}$ & $3,1 \times 10^{2}$ & $<10$ & $<10$ & $<10$ & $<10$ & $<10$ \\
\hline & C. albicans & $8 \times 10^{9}$ & $1 \times 10^{1}$ & $9 \times 10^{1}$ & $9 \times 10^{1}$ & $<10$ & $1 \times 10^{1}$ & $<10$ & $<10$ \\
\hline & E. coli & $5 \times 10^{9}$ & $<10$ & $<10$ & $<10$ & $<10$ & $<10$ & $<10$ & $<10$ \\
\hline & P. aeruginosa & $2 \times 10^{10}$ & $<10$ & $<10$ & $<10$ & $<10$ & $<10$ & $<10$ & $<10$ \\
\hline & S. aureus & $1 \times 10^{10}$ & $<10$ & $<10$ & $<10$ & $<10$ & $<10$ & $<10$ & $<10$ \\
\hline \multirow[t]{5}{*}{ G4 } & A. niger & $9,1 \times 10^{4}$ & $5 \times 10^{2}$ & $3 \times 10^{3}$ & $2 \times 10^{5}$ & $1 \times 10^{3}$ & $1 \times 10^{3}$ & $7 \times 10^{3}$ & $8 \times 10^{3}$ \\
\hline & C. albicans & $7.2 \times 10^{9}$ & $8 \times 10^{5}$ & $3 \times 10^{6}$ & $1 \times 10^{5}$ & $1 \times 10^{6}$ & $1 \times 10^{6}$ & $1 \times 10^{6}$ & $1 \times 10^{6}$ \\
\hline & E. coli & $9 \times 10^{7}$ & $4 \times 10^{3}$ & $3 \times 10^{3}$ & $3 \times 10^{3}$ & $1 \times 10^{4}$ & $<10$ & $6 \times 10^{3}$ & $1,3 \times 10^{4}$ \\
\hline & P. aeruginosa & $6 \times 10^{9}$ & $8 \times 10^{1}$ & $<10$ & $1 \times 10^{3}$ & $<10$ & $<10$ & $<10$ & $<10$ \\
\hline & S. aureus & $1.6 \times 10^{10}$ & $4 \times 10^{6}$ & $2 \times 10^{3}$ & $<10$ & $<10$ & $<10$ & $1,5 \times 10^{4}$ & $2 \times 10^{4}$ \\
\hline \multirow[t]{5}{*}{ (Buffer + neutralizer) } & A. niger & $9.1 \times 10^{4}$ & $9,1 \times 10^{4}$ & $3 \times 10^{4}$ & $6 \times 10^{4}$ & $1 \times 10^{6}$ & $1 \times 10^{6}$ & $1 \times 10^{6}$ & $1 \times 10^{6}$ \\
\hline & C. albicans & $7.2 \times 10^{9}$ & $8 \times 10^{5}$ & $9,2 \times 10^{5}$ & $1 \times 10^{4}$ & $1 \times 10^{6}$ & $1 \times 10^{6}$ & $1 \times 10^{6}$ & $1 \times 10^{6}$ \\
\hline & E. coli & $9 \times 10^{7}$ & $2 \times 10^{6}$ & $2 \times 10^{6}$ & $1 \times 10^{6}$ & $1 \times 10^{6}$ & $1 \times 10^{6}$ & $1 \times 10^{6}$ & $1 \times 10^{6}$ \\
\hline & P. aeruginosa & $6 \times 10^{9}$ & $1 \times 10^{6}$ & $2 \times 10^{6}$ & $2 \times 10^{4}$ & $1,2 \times 10^{6}$ & $1,26 \times 10^{6}$ & $1,26 \times 10^{6}$ & $1,26 \times 10^{6}$ \\
\hline & S. aureus & $1.6 \times 10^{10}$ & $2 \times 10^{6}$ & $2 \times 10^{6}$ & $1 \times 10^{6}$ & $2 \times 10^{6}$ & $2 \times 10^{6}$ & $2 \times 10^{6}$ & $2 \times 10^{6}$ \\
\hline
\end{tabular}

G1: Aroeira gel without preservation system; G2: Aroeira gel with preservation system; G3: Placebo with preservation system; G4: Placebo without preservation system.

antimicrobial activity against $S$. aureus and B. subtilis have been reported in the literature (Falcão et al., 2002).

Overall, these results are consistent with the studies of Campana et al. (2006) where the authors reported that formulations containing methylparaben associated with propylparaben showed broad spectrum of antimicrobial activity against the strains of $S$. aureus, $S$. epidermidis, $P$. aeruginosa and $P$. putida. Our results are also compatible with the results obtained by Guimarães et al., (1982). According to these authors, the result of the challenge test in kaolin suspension using a mixture of methylparaben, propylparaben and sorbic acid, revealed effectiveness of this preservative system against strains of A. niger, C. albicans and S. aureus.
Bou-Chakra et al. (1999), also reported the effectiveness of the preservative system with the challenge test in formulation of liquid soap against the bacteria $P$. aeruginosa ATCC 9027, S. aureus ATCC 6538, E. coli ATCC 10536 and against the yeast $C$. albicans ATCC 10231 and the filamentous fungus A. niger ATCC 16404.

Figure 3 indicates the reduction of two logarithmic cycles in the growth for $E$. coli and the reduction of four cycles for $S$. aureus in $24 \mathrm{~h}$, remaining unchanged until the end of the test for the "aroeira" gel without adding preservative (G1). These data indicate that the plant extract has preservative strength per se, especially towards S.aureus corroborating the antimicrobial activity observed by Leal et al. (1996), Martinez et al. (1996) and Melo Jr. et 
al. (2002).

Similar results were recorded by Remili et al. (1994) with other medicinal plant extracts. These authors reported that 9 medicinal plants extracts treated by spraydryer, revealed bactericidal activity through the challenge test against strains of S. aureus ATCC 6538 and E. coli ATCC 8539.

The results of this work are also consistent with the studies of Seo et al. (2002). These authors developed a preservative system that consisted of a mixture of chitosan and Inula helenium L extract, whose results presented excellent antimicrobial effect in cosmetic and transdermal formulations in the challenge test against strains of $A$. niger, C. albicans, E. coli, $P$. aeruginosa and $S$. aureus.

\section{Conclusion}

The method of the challenge test allowed for the evaluation of the formulation composed of a preservative system and $S$. terebinthifolius gel within 28 testing days. The formulation was considered adequately conserved by the system comprised of methyl and propylparaben, according to the criterion A advocated by the European Pharmacopoeia (2002) against the strains of A. niger, E. coli, $P$. aeruginosa, $S$. aureus and $C$. albicans.

Although antimicrobial activity of extracts of $S$. terebinthifolius is reported in the literature, the need for using preservatives was evident since there was no significant reduction in the microbial load for all microorganisms tested in the samples of hydrogel containing only the plant extract.

\section{References}

Arias ME, Gomez JD, Cudmani NM, Vattuone MA, Isla MI. 2004. Formulation and conservation of pharmaceutical form with leaf extracts from Acacia aroma Gill ex Hook et Arn. Rev Bras Farmacogn 14: 30-32.

Amorim MMR, Santos LC 2003. Tratamento da vaginose bacteriana com gel de aroeira (Schinus terebinthifolius Raddi): ensaio clínico randomizado. Rev Bras Ginecol Obstet 25: 95-102.

Bacchi EM 1986. Ação anti-úlcera e cicatrizante de algumas plantas brasileiras. Rev Bras Farmacogn 1: 93-100.

Bou-Chacra NA, Corrêa CJF, Ohara MT, Pinto TJ 1999. Avaliação de sistemas preservantes por regressão linear. Cosmet Toiletries 11: 44-48.

Campana R, Scesa V, Patrone V, Vittoria E, Baffone W 2006. Microbiological study of cosmetic products during their use by consumers: helth risk and efficacy of preservative systems. Lett Appl Microb 43: 301-306.

Falcão EPS, Silva NH, Gusmão NB, Ribeiro SMR, Honda NK, Pereira E 2002. Atividade antimicrobiana de compostos fenólicos do líquen Heterodermia leucomela (L) Poelt. Acta Farm Bonaerense 21: 43-49.

European Pharmacopoeia 2001. 4 ed. Dosage forms. Strasbourg:Edqm, p. 560.
United State Pharmacopoeia 2006. 294 ed. Validation of microbial recovery, United States Pharmacopeial Convention, INC. p. 3053-3054.

Guimarães EMP, Santos MM, Barduk O, Pinto TJA, Bertuzzi HJ, Saito T 1982. Eficácia de conservantes em suspensão de caulim. Rev Farm Bioq Univ São Paulo 18: 28-38.

Handbook of Pharmaceutical Excipients 1994. 2 ed. Pharmaceutical Press, p. 651.

Leal LB, Caetano N, Araújo E, Santana DP 1996. Preparação e avaliação antimicrobiana de formas geleificadas de uso vaginal da aroeira-da-praia (Schinus terebinthifolius Raddi). XIV Simpósio de Plantas Medicinais do Brasil. Florianópolis, Brazil.

Lorenzi H, Matos FJA2008. Plantas medicinais no Brasil-nativas e exóticas. 2 ed. Nova Odessa: Instituto Plantarum.

Manou I, Bouillard L, Devleeschouwer MJ, Barel AO 1998. Evaluation of the preservative properties of Thimus vulgaris essential oil in topically applied formulations under a challenge test. J Appl Microbiol 84: 368-376.

Martinez MJ, Betancourt J, Gonzalez NA, Jauregui A 1996. A screening of some Cuban medicinal plants for antimicrobial activity. J Ethnopharmacol 52: 171-174.

Matos FJA 1994. Farmácias vivas. Fortaleza: Editora da EUFC.

Melo Jr. EJM, Raposo MJ, Lisboa Neto JA, Diniz MFA, Marcelino Jr. CAC, Sant'ana AEG 2002. Medicinal plants in the healing of drug socket in rats. Phytomedicine 9: 109-116.

Ministério da Saúde 1994. Secretaria de Vigilância Sanitária. Portaria $n^{\circ} 123$ de 19 de outubro de 1994. Diário Oficial da União, Brasília.

Nostro A, Cannatelli MA, Morelli I, Cioni PL, Bader A, Marino A, Alonzo V 2002. Preservative Properties of Calamintha officinalis essential oil with and without EDTA. Lett Appl Microbiol 35: 385-389.

Remili H, Boussard P, Devleeschouwer M 1994. Microbiological quality of spray-dried pharmaceutical plant extratcs. Eur J Pharm Sci 1: 265-268.

Seo SB, Ryu CS, Ahn GW, Kim HB, JO BK, LEE JD, Kajiuchi $\mathrm{T}$ 2002. Development of a natural preservative system using the mixture of chitosan - Inula helenium 1 . extract. Int J Cosmet Sci 24: 195.

Simões CM, Schenkel EP, Gosmann G, Mello JCP, Mentz LA, Petrovick PR 1999. Farmacognosia: da planta ao medicamento. Porto Alegre/Florianópolis: Editora da UFRGS.

Vasconcelos EAF 2003. Caracterização de extrato seco por aspersão da Schinus terebinthifolius Raddi e validação de metodologia analítica para doseamento de taninos totais. Natal, 110 p. Dissertação de Mestrado, Programa de Pós-graduação em Ciências Farmacêuticas, Universidade Federal do Rio Grande do Norte.

\section{*Correspondence}

Túlio Flávio A. L. Moura

Departamento de Farmácia da Universidade Federal do Rio Grande do Norte

R. Brigadeiro Cordeiro de Farias, s/n, Petrópolis, 59.010-180 Natal-RN, Brazil

moura@ufrnet.br

Tel.: 558433429815 